\title{
Brexit: An Assessment of the Unprecedented Divorce Story and the Long Path to Ex-Membership
}

\author{
Gozde Kaya, PhD \\ Associate Professor of European Union Studies, Division of EU Law, \\ Department of International Relations, Faculty of Business, Dokuz Eylül \\ University, Izmir, Turkey
}

URL:http://dx.doi.org/10.19044/esj.2020.v16n17p1

\begin{abstract}
The UK which had been one of the major members of the EU, currently has been holding the status of an 'ex-member' following almost a four years of a rocky withdrawal process that took place for the first time ever in the EU history. This unprecedented withdrawal is likely to come up with severe negative outcomes particularly for the UK side in comparison to remaining in the Union. This study seeks to demonstrate the likely legal, political and economic ramifications of the British withdrawal by particularly concentrating on the highly critical and debated issues bargained during the withdrawal negotiations as well as to draw a detailed comparison of the outcomes of an exit under the framework of a withdrawal agreement and a no-deal scenario. Yet, the paper concludes that the second round of negotiations for determining on the terms of a future relationship might not be as less difficult than the first round examined in this study.
\end{abstract}

Keywords: Brexit, the United Kingdom, the European Union, Withdrawal, No-deal

\section{Introduction}

It's well-known that the European Union (EU) has been challenged by several major crises for the last decade. Brexit is to be regarded as only one of them which also covers the economic, migration, governance crises as well as the crisis of increasing Euroscepticism. Brexit as rightfully put forward by Nugent (2018) is not only significant in terms of setting a precedent for withdrawal from the Union, however it's also significant since the withdrawing country is regarded as one of the largest and most powerful countries of the EU (pp.54-55). Following a membership which had fully and uninterruptedly continued for 47 years, the United Kingdom (UK) has finally left the EU at 11.00 pm on 31 January 2020. This outcome which arose after 
a negotiating period corresponding to a political deadlock lasting for more than three and a half years, has attracted a lot of attention around the world. Everyone on that particular day, has witnessed such a cornerstone and historical moment that was cheerfully welcomed by the half of the country while was mourned by the rest. Though uncertain yet, it is inevitably expected to lead to considerable economic and political outcomes both for the UK and the EU. However, what is certain is that despite all these crises the EU has been undergoing, neither the citizens nor the institutions of the two sides, had fully understood the possibility that a Brexit might come true (Martill \& Steiger, 2018, p.1)

It's indeed not the first time that the UK has decided to hold a referendum on the continuity of its EU membership. Immediately after its accession to the then European Economic Community (EEC) in 1973, the UK held its first referendum in 1975 on whether or not to remain in the EEC. A large majority of British voters corresponding to $67.23 \%$ of the whole electorate chose to remain in the EEC and supported the Labour Government who campaigned for not leaving. ${ }^{1}$ (Martill \& Staiger, 2018, p. 5) However, currently the words of Edward Heath stressing that "the Community the UK was acceding in 1973 was far more than a common market" has not been well remembered. Similarly, the referendum held in 1975 has been misremembered as merely a trade vote and not much more than that (Cliffe, 2020, p.24). Almost forty years after that, the former British Prime Minister David Cameron had announced that he would hold a second referendum on the British membership of the EU on June 23, 2016. He also promised to conduct a strong campaign for convincing British citizens to stay in the EU (Economist, 2016, p.7).

According to Cini and Verdun (2018), one can assume that crisis times can even lead to deeper integration in the EU. This has been revealed following the Eurozone crisis which led to the introduction of new institutional structures, new institutional instruments, a new treaty and so forth. Likewise, the same may apply in the case of Brexit (p. 68). Yet, it's still early to make clear arguments about such a broad subject on how Brexit will affect the European integration process. Rather than that, this study will seek to analyse the possible effects of Brexit on the UK from an interdisciplinary approach trying to focus on the likely legal, political and economic outcomes despite of the still-lasting uncertainties at the time of writing. Brexit has raised several serious questions: What were/are the major controversial issues between the $\mathrm{UK}$ and the EU even before the British referendum, during the withdrawal negotiations and recently? What are the outcomes of Brexit under the

${ }^{1}$ 1975:UK Embraces Europe in Referendum, On This Day 1950-2005. BBC News Home.

Retrieved December 10, 2019 from

http://news.bbc.co.uk/onthisday/hi/dates/stories/june/6/newsid_2499000/2499297.stm. 
dynamics of a Withdrawal Agreement and a former no-deal scenario? This paper seeks to demonstrate that Brexit is likely to affect the UK in negative terms under each circumstance in comparison to preserving the full membership though it is regarded as one of the strongest and wealthiest Member States of the EU. The paper tries to reveal that even for such a powerful state, the withdrawal experience can still be such painful and longlasting yet full of much uncertainties, let alone other members of the EU. The research approach chosen in this study is largely based on a comprehensive literature review which is strengthened through recent official sources as well as the leading press agencies.

In that respect, the study is structured as follows: The first part of the study, focuses on the controversial issues raised between the UK and the EU before the Brexit referendum and explores whether or not there are any precedents for Brexit. The second part of the paper tries to figure out the likely legal, political and economic consequences of British withdrawal in general from an interdisciplinary approach. This is followed by the core part of the paper which tries to analyse the mostly debated controversial aspects/issues of the withdrawal negotiations and the bargaining process between the sides. Yet, the paper draws a comparison of the British exit from the EU within the framework of a Withdrawal Agreement as is the case now and a scenario of what it would have looked like if there would have been a no-deal situation with an aim of capturing a better understanding of the likely severe outcomes of the whole process. Lastly a brief analysis of the likely impact of the Covid19 pandemic is made in terms of the sides' on-going negotiations for determining on a future trade relationship.

\section{Negotiations with the EU on the Way to the Brexit Referendum}

After the general elections held in the United Kingdom (UK) in 2010, two crucial issues arose with regard to the UK's relations with two unions that the country was engaged in. One concerned the questioning of the long-lasting relationship of the UK with the EU while the latter one related to the issue whether or not Scotland should be independent from the UK (Gamble, 2012, p.468).

British demands to remain in the EU before the referendum indeed were not considered as a big deal since the UK has long before made a choice between what it liked and disliked with regard to the European integration. It opted out from the Euro, the Schengen area, most of the provisions in the area of police cooperation and judicial cooperation over criminal matters and has exemption from the European Court of Justice (ECJ) ruling on the application of the Charter of Fundamental Rights of the EU as well as a special budget rebate due to special arrangements. Therefore, the UK has already been having 
a beneficial status which is commonly referred to as 'having the best of both worlds' (Emerson, 2016, pp.2-5).

Before the negotiations between the UK and the EU were concluded, there was also the option of a 'half-membership' of the EU which was put on the agenda by some politicians particularly Boris Johnson. This alternative included a new type of membership in which the UK could remain in the EU by holding a special status. In that regard, the country was supposed to continue to have full access to the Internal Market and participate in the decision-making process of the Union as well as retaining the right to opt out of what it disliked at the EU level. The biggest problem of that alternative was that it necessitated the revision of the EU Treaties in order to allow granting such a special status to one of the Member States since the current Treaties do not allow any such possibilities (Piris, 2016, p.3). However, this option seemed quite risky in many aspects since it would have required the common agreement of all the Member States which accordingly was to be followed by the ratification processes in accordance with the Member States' constitutional requirements. Piris (2016) truly argues that even if one had ignored the complexity of the ratification procedures, still it would have taken years for all the members to go through this process. What's more, such a 'pick and choose' approach probably would not have been welcomed by some Member States which had considered the EU benefits and duties as a single package. This could also have led to the conclusion that the other EU-sceptic countries might have asked for the same status (p.3).

Cameron's negotiations with the EU covered four fundamental issues. Keeping in mind that the UK since the early 2000's -as a country that neither participated to the European Monetary Union (EMU) nor did hinder its introduction- was advocating that the EU should recognize that it encompasses more than one currency. According to the UK, the EU should avoid approaching prejudicial towards the Member States who still have been preserving their national currencies (Cini \& Verdun, 2018, p.69). Therefore, the first key matter was related to the UK's concerns to protect the city of London against financial market legislation which was decided by the eurozone majority of the Council. Since the UK was not a eurozone country, this was considered to be likely to lead to discriminatory results to the detriment of the city. Hence the UK demanded some necessary measures to be taken by the European Commission to assure the prohibition of discrimination between euro and non-euro economic actors (Emerson, 2016, p.4). In that respect, Cameron had asked for a mechanism which would give any noneurozone country the opportunity to halt the new legislation's decisionmaking process with regard to eurozone. Surprisingly his offer was accepted with the condition that only one non-eurozone country might have delayed this 
process to push for a further debate about any problematic eurozone legislation (Rankin, 2016).

The second one was linked to the competitiveness which covered the decrease of the red tape and the administrative burdens while leading to a better regulation that the European Commission has been working for. This also necessitated the repeal of unnecessary legislation as well as the conduct of a more aggressive trade policy which included the extension of the EU's liberalising trade agreements to the US, Japan, Latin America and Asia-Pacific countries that was also likely to serve to British interests (Emerson, 2016, p.4).

The third issue focused on the sovereignty and the 'ever-closer union' idea which raised distressful concerns on the UK that the European integration was proceeding continuously towards a federal mechanism. Hence, the UK was guaranteed that the 'ever-closer union' phrase should not be considered as a legal basis for a further constitutional change. What's more, the country asked for the recognition that it was not willing to proceed with any deeper political integration and that not all the EU Member States were obliged to pursue a common goal with regard to the integration (Emerson, 2016, p.4). The UK this time sought for a stronger guarantee than what had already been agreed by the Member States as a special formula of wording in June 2014 that "not all the Member States were on the road to integration" and the EU leaders accepted this recognition (Rankin, 2016). This was indeed unsurprising since the UK is always regarded to be the voice of opposition and scepticism when it came to further integration matters of the Union (Cini \& Verdun, 2018, 67). The UK also demanded the introduction of a new 'red card' mechanism to be built on the existing 'yellow' and 'orange' card mechanisms which strengthen the role of the national parliaments in the EU decisionmaking procedure (Emerson, 2016, p.4). Departing from the fact that the yellow card mechanism was used very rarely, the red-card mechanism was also criticized for how likely it was to be invoked. However, it was mainly sought to be introduced to built up alliances among the Member States for effectively blocking a Commission proposal (EU Reform Deal, BBC News, 2016).

The last issue pointed out by the UK was regarded as a sensitive one which related to the social benefits provided to intra-EU migrants. The UK asked for measures to be taken to tackle the so called 'benefit tourism' without damaging the free movement rights and the principle of non-discrimination on grounds of nationality. This measure was referred to as a new 'alert and safeguard mechanism' or 'an emergency brake'. It was to be invoked in cases of high inflow of workers causing excessive pressure on the proper functioning of the public services in some particular Member States (Emerson, 2016 , p.4). Cameron had asked for a four-year freeze on the social benefits of the European citizens working in the UK. However, through the end of the 
summit, he accepted that the emergency break would only cover the new comers. Furthermore, his demand for keeping the emergency break in force for thirteen years was accepted only for seven years corresponding to a period which the UK had conducted an open-door policy to the nationals of Central and Eastern Member States when most of the other Western European countries had closed their labour markets in 2004 (Rankin, 2016).

Cameron and the EU leaders had finally reached an agreement at the European Council held on 18-19 February 2016 on these four requests put forward by Cameron's government for ensuring the UK's remaining in the EU (Emerson, 2016, p.1). However, it was the referendum which had the final say on whether or not the UK should have continued to remain as a member of the EU. The turnout for the referendum was $72.2 \%$. The outcome was striking that the British people chose to leave the EU with a $51.9 \%$ of voters voting to leave corresponding to 17.410 .742 votes while a $48.1 \%$ of voters choosing to remain in the EU with 16.142.241 votes. It is crucial to note that in Northern Ireland and Scotland, the remain side was overwhelming whereas in England and Wales, the leave side was prevailing (EU Referendum Results, BBC News, 2020).

David Cameron resigned and his successor Theresa May was expected to trigger Article 50 of the Treaty on the Functioning of the EU (TFEU) for the start of an official withdrawal from the Union (Martill \& Staiger, 2018, p.6). However, the UK Supreme Court decided in case Miller ${ }^{2}$ that an act of the UK Parliament was necessary for authorising the government to trigger Article 50 TFEU. In that regard, the UK Parliament passed the European Union (Notification of Withdrawal) Act 2017 on 13 March which received the royal assent from the Queen on 16 March 2017 (Carmona, et al. 2017, p.3). Hence, the official letter for British withdrawal was submitted to the EU on 29 March 2017 (Martill \& Steiger, 2018, p.6).

Coe (2019) rightfully questions to what extent the Brexit referendum primarily concerned the vote for the UK's full membership in the EU. The polls recorded before the referendum revealed that though this referendum targeted the UK's full membership, the Brits implicitly were more concerned about matters related to immigration, financial crisis, housing, education, health and welfare which were well marketed and easily filled with populist discourses (p.34). Hence a considerable number of British citizens carried their dissatisfactions to the poll while Cameron was strongly advocating in favour of remaining.

${ }^{2}$ Judgement of the UK Supreme Court of 24 January 2017, $R$ (on the application of Miller and another) (Respondents) v. Secretary of State for Exiting the European Union (Appellant). 


\section{Any Precedents for Brexit?}

The only precedents which shed some light and reveal some possible consequences of withdrawal from the EU are Algeria's and Greenland's withdrawals from the European Community (EC) in 1962 and 1985, respectively. Algeria became a member of the EC as a part of France. The country went into a war of independence that lasted for eight years and finally reached its independence after which it withdrew from the EC (Patel, 2018, p.115). Immediately after its withdrawal, Algeria sought for some ways to preserve the existing EC legislation in its national legal system and still was treated as a Member State for some time. However, during the 1970's, the country's close ties with the EC market started to weaken on a gradual basis. Particularly, the protectionist feature of the EC's common agricultural policy had a considerable negative impact on the wine production of the country which was the world's biggest exporter during the 1960's. In time, the EC started to treat Algeria like any other North African country (Patel, 2018, pp.116-118).

The case of Greenland which though is not a state but a Danish dependency, can also give some idea on the possible effects of the withdrawal. Joining the EC involuntarily as an independent part of Denmark in 1972, Greenlanders decided to leave the EC through a referendum only ten years after its accession in 1982 (Patel, 2018, p.115; Berglund, 2006, pp.157-158). After Denmark's proposal to the EC to grant Greenland the status of Overseas Countries and Territories -which was the most beneficial solution for Greenland- the European Commission accepted the proposal and the parties set a compromise about the consequences of this withdrawal. Having the status of Overseas Countries and Territories meant much to Greenland since it allowed the country still to have tariff-free access to the Internal Market for exporting its fish and fish products as well as receiving some limited loans from the EC (Berglund, 2006, p.158). In return, the EC Member States led by Germany were granted the right of fishing in Greenlandic waters. Hence, the Fisheries Agreement concluded between the sides, ended the negotiations of Greenland's withdrawal from the EC. Yet, it can be argued that the terms of withdrawal were still beneficial rather than costly for Greenland to leave the EC (Berglund, 2006, p.159).

Both in the Algerian and Greenlandic cases, the two countries while seeking for their full sovereignty and independence on one side, they still searched for ways to preserve their close links to the EC particularly due to economic reasons. What is also to be underlined in both cases is that the intention of accession to the EC belonged to the motherlands of those countries. People of neither Algeria nor Greenland could deliver their independent decisions on whether or not acceding to the EC (Patel, 2018, pp.115-116). Yet, the situation of the UK is completely different from those 
two cases. It became a Member State as a fully independent country acting on its own peoples' will.

\section{Some Concerns about Possible Political and Legal Aspects of Withdrawal}

Though it's been four years after the referendum, still the consequences of the British withdrawal from the EU yet remain unclear and go no further than estimations through legal, economic and political aspects. However, it's certain that the withdrawal from the Union will inevitably have far-reaching political, legal and economic consequences both from the perspectives of the withdrawing Member State as well as the remaining members of the EU.

As pointed out by Emerson (2016), immediately after the withdrawal, the Treaties shall cease to apply to the withdrawing state as laid down under Article 50 TFEU. This corresponds to an EU legislation comprising around 5000 regulations, directives and decisions with regard to the Internal Market and almost 1100 international treaties concluded between the EU and the third countries (p.6). However, it does not seem possible that this wide category of EU legislation would automatically be repealed and deleted from the British legal system since they were transposed to national legislation and have been implemented by the British judiciary during full membership (p.6). Hence, a repeal of the 1972 British European Communities Act within the exit day would necessitate the British legislator to enact new laws to fill such an extensive legal gap (Piris, 2016, p.12). Nicolaides (2013) reminds that the withdrawal from the EU does not necessarily bring together an obligation to change all the national legal system of the withdrawing country. In other words, it would be up to the choice of the withdrawing country whether or not to keep the relevant EU legislation in force in its national legal system. If it would be to the interest of the withdrawing country to continue applying the EU standards in a policy field such as environment, it shall keep the relevant legislation (p.215). Besides, the UK would also need to set up new mechanisms or institutions to replace particularly the tasks of the European Commission in areas which it enacts new national rules and policies (p.216). Yet, the practical realities with regard to legal changes indeed seem to be highly problematic in that regard.

Referring to Apolte's recognition of 'withdrawal from the Union' as 'secession' (Apolte, 1997) Berglund, in her analysis questions whether or not such a withdrawal from the EU has common characteristics with 'the right of secession' under international law. According to Berglund (2006), the concept of secession particularly includes claims to territory and therefore might not be sufficiently appropriate to invoke in a withdrawal situation. Still, she 
accepts that secession might show similar characteristics to a withdrawal case. (pp.154-155).

Therefore, focusing on the secession literature and some common points thereof, she draws out five issues to be analyzed in case of a withdrawal from the EU. These can be listed as territory, legitimacy of leaders, fear of fragmentation, lost investment and costs to be borne by all sides. However, three issues are of significant concern when the EU is considered. The first one is the fear of fragmentation which Berglund argues that a withdrawal from the Union by a particular Member State is likely to lead to the follow up of others. In that context, the writer argues that such a move would be risky in terms of becoming the starting point of a possible breakdown of the EU. According to the writer, the stronger the withdrawing Member State is, the heavier the fear of fragmentation is to be felt among the EU members (Berglund, 2006, p.155 and p.162). That's one of the reasons why the EU Member States would seek to guarantee that the UK would not get a too good deal with the EU according to some arguments put forward immediately after the British referendum (Cini \& Verdun, 2018, p. 68). Currently, four years after the referendum, it seems that there exist no such risks related to the follow up of any EU 27 Member States. Though there are no short-term signals for any such effect, still the Brexit referendum constitutes a serious challenge to the EU integration and there is always the risk that such effects might rise at some point in the future (Cini \& Verdun, 2018, p.68).

It's noteworthy that the withdrawal of such a major Member State is likely to jeopardize the European integration project and affect negatively the international political actorness of the EU (Berglund, 2006, pp.162-163). Apart from that, Emerson (2016) argues that the UK also has a lot to lose in terms of its foreign policy due to the withdrawal. It's well-known that the UK had always been retaining its freedom to act independently from the EU when it came to foreign policy matters. Moreover, the US as well as China had even declared that they would have preferred the UK to remain in the EU (p.21).

Another point raised by Berglund (2006) to take place in withdrawal cases concerns the effects of Europeanization. It's known that most of the EU Member States have introduced several policy changes or legal amendments in order to become a full member to the Union. This even required some constitutional amendments in several Member States. Therefore, the withdrawal is likely to affect the system created by the Europeanization process in that particular Member State. It will not be wrong to assume that the withdrawal might be more difficult and challenging for an old Member State such as the UK which has long absorbed and internalized the Europeanization process throughout its full membership in comparison to a newly welcomed state (pp.156-157). 
Thirdly, there exists the lost investment issue which corresponds to the investments such as the infrastructural or the industrial contributions made by the remaining state within the territory of the seceding state. However, this can be solved through a compromise that may satisfy both parties and this issue is not likely to be of great concern in Brexit case since the EU investments are generally limited in scope (Berglund, 2006, p.156).

It is also noteworthy that the withdrawing state faces the risk of the decrease of both education and employment opportunities to be exercised by its citizens living in other Member States following the withdrawal (Berglund, 2006, p.162). When the UK abandons the free movement of persons, it will have negative effects both on the EU citizens living in the UK as well as the British citizens who have been residing in other EU Member States on a reciprocal basis. Normally, both citizen groups shall be subject to the need to take work permits for a further settlement in the host countries which will take quite long time and extra procedures. EU citizens engaged in several group of professions ranging from unqualified to qualified shall no more find any opportunities as easy as earlier in the British labour market which inevitably is to be affected by this situation. In that regard, British labour market is likely to turn out to be less flexible while covering a narrower group of skills in comparison to past (Emerson, 2016, p.11). What's more, not only individuals but also companies both belonging to the UK and other EU countries are assumed to be suffering from the same disadvantage (Piris, 2016, p.12).

Another disadvantageous situation concerns the generous social security arrangements implemented for British retirees living abroad particularly in the Mediterranean region. It is assumed that those retirees who are heavily dependent on this system in terms of services such as health care shall no longer be able to demand the implementation of EU norms in that regard. Likewise, British students studying abroad in Europe are also likely to be affected. Taking into consideration the significant role the UK plays within the EU education system as well as the European wide academic research pool, the outcome of abandoning the free movement of people is likely to cause similar negative effects for British universities as well. Accordingly, the Erasmus programme for education and the Horizon 2020 programme for academic research are also likely to be affected negatively (Emerson, 2016, pp.11-12).

Emerson (2016) even goes further by putting forward the possibility of the UK asking for visas with regard to EU citizens in order to hinder the pressure of immigration which might emerge on a reciprocal basis (p.12) though it appears as a small possibility. Yet most of these issues related to the situation of both sides' citizens are already regulated under the withdrawal agreement (Piris, 2016, p.12). 


\section{Some Concerns about Possible Economic Costs of Withdrawal}

Economic costs are highly significant for both sides when it comes to the withdrawal case. As Emerson (2016) truly puts it, the political, institutional and the legal consequences of the withdrawal are more likely to be predicted in comparison to economic results which yet remain unclear (p.6). This shall also largely depend on the terms of the future trade relationship between the sides. However, following such a withdrawal, the costs borne are likely to be higher for the part which is poorer than the other side in terms of economic conditions. Berglund (2006) argues that in cases of secession, where the seceding state is less wealthy and in need of receiving financial contributions from the remaining state, the seceding state might face economic difficulties upon secession. However, if the opposite is the case where the seceding state is richer and a net-contributor to the remaining state, then the remaining state might not be willing to allow the other's secession (p.156).

If this assumption is applied to the case of a withdrawal from the EU, then it's likely that the costs will arise depending on whether the withdrawing Member State is a net receiver of EU funds or a net contributor. In that regard, a net receiver state is likely to lose the aids to be achieved from the EU while a net contributor is likely to benefit from this situation. Taking British withdrawal into account, the UK is to be regarded as a net contributor to the EU budget. However, following the withdrawal, the UK shall no more be obliged to contribute to the three most costly EU policies namely the common agricultural policy, the regional policy and the research policy. Yet, this shall also mean that British farmers, British researchers and the less developed regions will no more be able to benefit from the EU funds (Nicolaides, 2013, p.216). From the EU side, loosing such a major contributor to the common budget will lead to serious questions like which country would be filling this gap instead. Paterson (2018) in that regard points out to the lonely position of Germany which is expected to finance the gap as the largest and wealthiest country in the EU (p.92).

The costs to be born also shall differ depending on whether or not the withdrawing Member State takes place in the European Monetary System (EMU). In that context, it shall face the costs of reconstituting its national currency (Berglund, 2006, p.162). However, this shall not appear in the case of British withdrawal since the UK is already not a member of the EMU and the Eurozone.

According to Berglund (2006) the costs of loss of access to the Internal Market could be high for the withdrawing Member State. The costs are expected to be higher in cases where the dependency of that state on the EU area is high in terms of its exports and imports (p.162). Taking into consideration the relationship between the UK and the EU, one has to note that the EU is the UK's largest trade partner. UK exports to the EU amounting to 
a trade volume of $£ 289$ billion corresponded to $46 \%$ of all UK exports by 2018. On the other hand, UK imports from the EU amounted to $£ 345$ billion and held a share of $54 \%$ among all UK imports for the same year (Statistics, House of Commons, 2019). Hantzsche, Kara and Young (2019) estimate that the GDP (Gross Domestic Product) per capita of the UK and accordingly the economic growth of the country by 2030 are likely to be lower under each scenario after Brexit in comparison to the lost alternative of preserving the EU membership (pp.5-6).

Another point to be highlighted is that due to withdrawal, the UK is likely to lose its beneficial position with regard to London's role in the EU financial market and the foreign direct investment (FDI) it attracts from the rest of the world (Emerson, 2016, p.9). Particularly, the situation linked to the financial markets is of significant value since the financial center of the Euro would probably be changed into another leading city other than London which would already be located in the Eurozone after such a withdrawal (Emerson, 2016, p.15). The name of Frankfurt -as the city hosting the European Central Bank- is frequently discussed and considered most probably to replace London as the financial center under such a circumstance despite the counter opinions (Mc Grath, 2018; Bicer, 2019).

\section{Exiting from the EU within a Withdrawal Agreement}

Before the start-up of the official negotiations between the EU and the UK, there were several debates among scholars with regard to how these negotiations might have proceeded. According to Emerson (2016) it was more likely that the UK could have been trying to negotiate a pleasing deal for tarifffree trade without full access to the Internal Market, particularly by abandoning the free movement of people and persuading the EU for a selective inclusion in the Internal Market. Emerson called this a 'subtraction method' in which the seceding country chose the beneficial parts of the Internal Market rules while putting the irritating ones aside (pp.9-10).

The same method was called as a kind of 'pick and choose' model by Piris which was indeed similar to a 'half-membership' model (Piris, 2016, pp.5-6). However, Emerson (2016) argued that the EU, particularly the Commission would not have been much willing to conclude such a deal with the UK since the withdrawal would put the EU into difficulty by creating a reputational damage. What's more, the EU would most probably abstain from showing an impression to the other Member States that such a withdrawal case would not be as difficult and costly as it would have seemed. This method was also referred to as 'cherry picking' in the EU environment. However, as observed from the negotiations conducted between Switzerland and the EU after the Swiss referendum held in 2014 to abandon the free movement of 
people, this was indeed something which the EU had not been seeking for, since the EU always considers all the EU policies in unity (pp.10-11).

The official withdrawal negotiations between the UK and the EU started on 19 June 2017 and lasted up until 29 March 2019 during Theresa May's government (Martill \& Staiger, 2018, p.6). A withdrawal agreement was eventually reached by May's government and the EU on 25 November 2018 alongside a political declaration on the future relationship adopted by the parties on the same date. These two documents which are revised afterwards, were to be evaluated together on the common basis that "nothing is agreed until everything is agreed" (Explainer, Political Declaration, 2018, p.2). This meant that the negotiations with regard to the future relationship would continue and the withdrawal agreement would not have been signed until or unless a political declaration was reached on the terms of the future relationship between the two sides (Explainer, Withdrawal Agreement, 2018 p.2). A separate agreement is needed for determining on the conditions of a future relationship since it would require a negotiating process to last up for more than two years which is already over.

Furthermore, it was commonly agreed by legal scholars that the two agreements should not have been concluded at the mean time due to the lack of a legal basis. Article 50 TFEU which is the legal basis for withdrawal should be implemented between the EU and the withdrawing Member State which still is a member. However, when the specific terms and the content of the future relationship are to be determined, the withdrawing Member State shall be counted officially as a third country. So that, the legal basis of this relationship might be a provision such as Article 207 TFEU, 218 TFEU or 271 TFEU which relates to common commercial policy, negotiation and conclusion of international agreements and association agreements, respectively. Therefore, the withdrawal agreement and the agreement with regard to the future relationship are best thought to be concluded by following each other (Flavier \& Platon, 2016; Carmona et al. 2017, p.11) as is the case now.

The Withdrawal Agreement which is to be considered as an international treaty in its material substance comprises and seeks to clarify major controversial issues between the sides paving the way to the making of a future trade deal. The approval period of the former Withdrawal Agreement at home by the British Parliamentarians after its conclusion had been more painful than what had been envisaged by May. Among all tough issues, the most debatable ones could be listed as citizens' rights, financial settlement and the unique situation of Northern Ireland (Explainer, Withdrawal Agreement, 2018 pp.2-3). Yet considerable importance is to be attached to the circumstance in Northern Ireland which attracted much of the tension. The situation in Northern Ireland was regulated in May's Withdrawal Agreement 
within a Protocol concluded between Ireland and Northern Ireland. The hottest debate centred around the so-called 'backstop clause' introduced by the parties basically for the aim of avoiding a hard border between Ireland and Northern Ireland through fully respecting the rights enshrined in the Good Friday (Belfast) Agreement of 1998 (Commission Fact Sheet, Protocol Northern Ireland, 2018, p.1).

The backstop clause was to be regarded as a guarantee which would have only entered into force in case that the parties could not have agreed on any other solution with regard to a future relationship till the end of the transition period ${ }^{3}$ corresponding to 31 December 2020. Though both the British and the EU side hoped that the backstop clause had never taken effect, it was indeed provided for hindering the most negative outcomes of a Brexit to have taken place without any future trade deal (Wright \& Naselli, 2018). The backstop clause set out a single EU-UK customs territory in which there would have been no tariffs, quotas, or controls between the two sides. In that regard, EU's Customs Code and certain pieces of legislation with regard to EU's Internal Market would have continued to be applied to Northern Ireland to avoid a hard border (Commission Fact Sheet, Protocol Northern Ireland, 2018, p.1). The most disliked point with regard to the backstop clause was if it had entered into force, it might have restricted the UK's ability to conclude trade agreements with third countries since the country would still have remained in a customs union relationship with the EU (Wright \& Naselli, 2018). The facts that the backstop clause had been envisaged for an indefinite period and that the exit had been set to be conditional upon the approval of the EU were interpreted as conditions which were likely to trap the UK in the EU's customs territory (Kentish, 2019).

A second crucial matter to be dealt with May's Withdrawal Agreement was the clarification of the future rights and duties of both UK citizens living in the EU Member States and European citizens who had settled in the UK. Part Two of May's Withdrawal Agreement laid down Citizens' Rights to be applied particularly during the transition period. Individuals rightfully needed to be guaranteed that their rights would be protected and ensured legal certainty under the Withdrawal Agreement. In that respect, all the UK citizens legally residing in any of the Member States as well as all European citizens

\footnotetext{
${ }^{3}$ Transition period which is often referred to by the British side as "implementation period" aims to provide time to the parties to reach a compromise on a future trade deal after the withdrawal. So that, the UK shall still be bound to the EU's rules and be subject to the ECJ's case law to the degree that it is regulated under the Withdrawal Agreement. See, Taylor, C. (2018, October 22). Brexit Explained: What is the Transition Period and Why is it so Important? Irish Times. https://www.irishtimes.com/news/world/europe/brexit-explained-what-is-the-transitionperiod-and-why-is-it-so-important-1.3671622.
} 
legally residing in the UK at the end of the transition period would still be entitled to remain in their host states. The same rights should apply to their family members residing at the host state by 31 December 2020 (Explainer, Withdrawal Agreement, 2018, p.8). Citizens of both parties who had been legally and continuously residing in their host countries for five years at the end of the transition period should be granted a right of permanent residence in their host countries. Individuals belonging to both parties including workers, self-employed people or frontier workers all should be provided the same rights and protected in terms of the principle of equal treatment, free movement, mutual recognition of professional qualifications and social security benefits (Explainer, Withdrawal Agreement, 2018, pp.8-11).

Another controversial issue between the parties related to the clarification of the jurisdiction of the ECJ. The UK and the EU eventually agreed that the UK would continue to be bound with the ECJ's jurisdiction during the transition period and in some certain circumstances, beyond. UK courts would be able to ask for a preliminary ruling from the ECJ for matters concerning the interpretation of the Citizens' Rights part of the Withdrawal Agreement for eight years from the exit day (Explainer, Withdrawal Agreement, 2018, pp.11-12).

The next debatable issue concerned the financial settlement of the parties on matters related to the divorce. The financial settlement between the parties concerned both the UK's financial commitments to the EU and the EU's financial commitments to the UK. The Withdrawal Agreement particularly set out and clarified the financial obligations of the UK that it had undertaken earlier under the EU budget plan for the period 2014-2020. With regard to 2019-2020, the share of the UK would be calculated in accordance with the methodology exercised for its annual EU budget contributions. Payments to be made after the end of the transition period would be calculated according to the UK's average share of contributions to the EU budget for the period 2014-2020 (Explainer, Withdrawal Agreement, 2018, pp.30-31). In that respect, the UK's financial commitments yet far from being certain, were estimated to range between $£ 35-39$ billion. The UK would continue to contribute for the same period to the European Development Fund as well as EU Trust Funds and the Facility for refugees in Turkey. Another set of liabilities on the UK side covered the pensions and employee benefits of the members and staff of the European institutions. The UK was expected to contribute to these pension rights to have risen before or at the end of the transition period. Concerning the EU's major commitments, the UK would also be reimbursed for its paid-in capital share in European Investment Bank and European Central Bank over a certain period as had been agreed in the Withdrawal Agreement (Explainer, Withdrawal Agreement, 2018, pp.30-32). 
The Withdrawal Agreement concluded during May's term of office due to disagreement with regard to these controversial issues was rejected three consecutive times at the House of Commons. On the first vote held on 15 January 2019, 202 MPs voted in favour of the Withdrawal Agreement with 432 MPs voting against. In the following vote held on 12 March 2019, 242 MPs voted in favour of the Agreement with 391 MPs voting against. In the third and the final vote of 29 March 2019, the difference between the two sides decreased to only 58 votes with 286 votes in favour and 344 votes against. It's seen that the number of conservative MPs who voted in favour of the Withdrawal Agreement raised on a gradual basis from 196 recorded in the $1^{\text {st }}$ vote up to 277 within the last vote (Brexit: MPs reject, BBC News, 2019).

Yet, still this number was not sufficient for Theresa May to pass the Withdrawal Agreement from the British Parliament. May tried to renegotiate the Agreement with the EU in order to provide some more guarantees in terms of the hotly debated issues. However, the EU officials as well as political leaders of some major Member States such as France, already announced that the Withdrawal Agreement was not open to any renegotiation. In other words, the EU was not open to any reconsideration unless the UK totally changed its political line (Henley, 2019). In that regard, Theresa May, particularly due to failing to pass the Withdrawal Agreement and deliver Brexit, decided to resign both from her post as Prime Minister and from Tory leadership officially on 7 June 2019 (Mackrell, 2019).

A further point to raise is the difficulty in catching up with the official British withdrawal dates due to the long-standing controversies having been unresolved in the context of the Withdrawal Agreement. UK's first official leave date from the EU which was expected to take place on 29 March 2019, was initially shifted to 12 April and then finally to 31 October 2019. Theresa May remained as Prime Minister until her successor Boris Johnson, -a major name for leave side during Brexit referendum campaigns- took office as the new Prime Minister of the UK on 24 July 2019.

The Withdrawal Agreement eventually concluded between Johnson's government and the EU passed within such a limited period of time from the British Parliament with 621 to 49 votes in favour of the Agreement. However, the revised Withdrawal Agreement is considered largely to be built on May's Withdrawal Agreement except a few significant issues particularly concerning the situation of Northern Ireland. In other words, it does not bring forward major changes to May's agreement (O'Carroll, 2019). According to Article 4 of the Protocol on Ireland and Northern Ireland included in Johnson's revised Withdrawal Agreement (Revised Protocol, 2019), Northern Ireland shall remain as a part of the customs territory of the UK. However, Northern Ireland shall also be bound with a comprehensive list of EU law rules enshrined in the Annex II of this Protocol as well as Article 30 TFEU prohibiting any customs 
duties and charges having equivalent effect on imports and exports between Member States and Article 110 TEFU prohibiting any internal taxation to be imposed on products of other Member States in accordance with Article 5 of the revised Protocol. The same article also provides that quantitative restrictions on imports and exports shall be prohibited between Northern Ireland and the EU. To put it differently, Northern Ireland shall leave the EU's customs union with the UK. However, it will still partially be attached to the Internal Market of the EU. This significant arrangement is interpreted by some scholars as one of the major reasons behind Johnson's winning the deal. The main difference between May's deal and Johnson's deal lies with this arrangement which precisely guarantees that the UK does not remain in a customs union relationship with the EU. As rightfully pointed out by Walker (2019) this might look officially true in legal terms but not fully functionable under practical terms. Yet, the time will show how it will proceed.

\section{The Scenario of Exiting from the EU without any Withdrawal Agreement}

Yet, the prospect of a "no-deal" or "hard Brexit" did not come true. However, within the coming into office of Johnson, it's undebatable that at least for some time it had become a serious likelihood for the UK to crash out of the EU without a deal. Though the House of Commons voted by 312 to 308 votes in mid-March 2019 to reject a no-deal Brexit (House of Commons vote, British Parliament, 2019), still this was considered as a real possibility. It is fair to suggest that this 'worst of all possibility' would be likely to have severe effects concerning several aspects of the relationship if it had turned out to be true. Yet, in this part, the likely outcomes of what it would look like if the UK had exited from the EU without any withdrawal agreement shall be analyzed. According to Berglund (2006) the costs of withdrawal for the withdrawing state depends particularly on the fact whether or not that state is successful in concluding a beneficial agreement with the EU while leaving. In other cases, it definitely seems to be costlier when a withdrawal agreement cannot be reached between the sides and the state decides to withdraw unilaterally (p.162).

One shall remember that indeed Theresa May had put forward a tough stance with respect to a no-deal possibility when she said through her famous words that "a no-deal is better than a bad deal" in the early days of the negotiation process. Taking such a stance, she emphasized that her government would not allow the EU to urge and to force a bad deal that was not in line with British national interests or economy (Dominiczak, 2017). Long after this discourse and short before she had resigned, May said in an interview that her words were expressed in terms of the abstract and yet the Withdrawal Agreement concluded between the parties was indeed a good deal 
for the country (Isaby, 2019). Yet, according to some commentators, it still remains unclear whether or not Theresa May in the very beginning had put it seriously or just tried to invoke it as a tactic for negotiations (Mc Kee, 2018). Several reports and scenarios during the last four years have been put forward by many institutions such as the International Monetary Fund (IMF), Bank of England and Office for Budget Responsibility (OBR) with a view to assessing the likely disastrous effects of Brexit particularly on economy and trade. Yet, it is not possible to fully cover the likely catastrophic effects of a no-deal scenario on economy and particularly the financial sector of the UK within the limited scope of this paper if that prospect had come out to be true. Still it's significant to try to investigate the likely negative consequences of a no-deal scenario in order to fully enlighten the whole process and to comprehend how much worse things could have gotten if the highly criticized Withdrawal Agreement had not entered into force.

First of all, it's crucial to note that there would have been no transition period in case that the UK had left the EU without a Withdrawal Agreement. This would have meant that the EU law would have immediately ceased to apply in the country starting from the exit day. According to the early projections put forward by the Office for Budget Responsibility (OBR), in case that the UK had left the EU without a deal, this would have been likely to hit British economy into a recession towards the early 2020. Roughly, a nodeal scenario even with a positive approach, would have been likely to cause the GDP of the UK to fall by $2 \%$ while triggering the unemployment above 5 $\%$ through the end of 2020. These might have been accompanied by a comprehensive reduction in tax revenues and a major increase in national debt of the country. The OBR estimated that the growing ambiguity and diminishing confidence on the area of investment and trade in the country might have paved the way for a recession as disastrous as the one challenged during the 1990's (Elliot, 2019). It would have been unsurprising that the fall in tax revenues had been likely to lead to the reduction of funds dedicated for health and social care (Mc Kee, 2018).

A highly significant and yet unclear issue was whether or not the UK would still have been honoring its financial commitments in case of leaving the EU without a deal. In such a situation, the UK's financial contributions to the EU budget would have fallen to zero starting from the exit day. Darvas (2019) put forward some calculations according to what might have happened in terms of the non-payment of the exit fee if a no-deal scenario had taken place. Though he considered the amount of the exit fee to be low in comparison to Gross Domestic Product (GDP) both for the EU Member States and the UK sides, still he accepted that in such a circumstance, this financial gap as referred to "Brexit hole" in the EU budget would have to be filled particularly by the contributions of the rest EU 27 Member States. Wolff 
(2019) emphasized that indeed this gap would have to be filled by the EU's existing 'own resources' ceiling which would have been transferred to the EU budget by the Member States in accordance with their Gross National Incomes (GNI) (pp.1-3). Yet, Darvas (2019) pointed out to a possibility that even in the absence of a Withdrawal Agreement, the UK might still have chosen to comply with its financial liabilities for revealing its goodwill in terms of not losing any possibility of making a good trade deal with the EU in the future. If the UK had honored its financial liabilities, then the sides might still have made a cooperation on urgent matters even in the case of withdrawal without a deal. Otherwise, the EU might have perceived this as a hostile step whose consequences might have been more troublesome (Wolff, 2019, pp.1-3).

Leaving without a deal was likely to have one of its most immediate negative outcomes with regard to the trade relationship between the parties. Taking into consideration that both the UK and the EU were engaged in such a highly intertwining trade relationship due to British membership, a no-deal situation would have had immediate severe effects in trade relations. It was interesting to note that Dominic Raab -the new foreign secretary of Britainhad been urging British companies to expand their export area beyond European market particularly to Asia (Walker, 2019). More interesting than that was what he had been offering in terms of a no-deal Brexit when he had claimed that a no-deal exit indeed would have been likely to facilitate the negotiation and bargaining processes of a future free trade deal with the EU (Rankin, 2019). However, this claim was not accepted by the EU side as well as many scholars working in the field.

As indicated earlier, the volume of the trade relationship between the sides is quite large and it is doubtless that Brexit is likely to have an inevitable negative impact under each scenario in comparison to preserving the full membership. Yet, the UK most probably would have started to implement the World Trade Organization's (WTO) most-favoured nation tariffs immediately if it had left the EU without a withdrawal deal. However, that possibility still might come true if the UK and the EU will not be able to reach a compromise on the nature of their future trade relationship till the end of the transition period that corresponds to the end of 2020. A withdrawal with no-deal would have been likely to produce immediate challenges with regard to logistics and administration. Both sides would have had to recruit new personnel for taking charge in customs controls, veterinary, sanitary and phytosanitary checks (Wolff, 2019, pp.4-6). Keeping in mind that the EU is the biggest trading partner of the UK, these issues which seem to have been quite challenging to overcome are to be laid down under the terms of a future trade relationship between the sides in the short run.

One of the most significant outcomes which interestingly might have also been considered as one of the main reasons behind a withdrawal without 
a deal had concerned the border between the UK and Ireland. The backstop clause might have been the major incentive for British parliamentarians to reject May's Withdrawal Agreement. On the other hand, as rightfully argued by Wolff, this rejection most probably resulting in a no-deal withdrawal paradoxically would have necessitated customs controls at the border which had been aimed to be prevented with the backstop clause (Wolff, 2019, p.6).

Another outcome of leaving without a deal had been likely to arise with regard to the national health sector of the UK. Spencer (2019) made a reference to a Health Policy paper which stated that all scenarios with regard to Brexit, had indicated that the workforce of the national health sector would have been likely to diminish, yet the care for British citizens who had settled in the EU Member States would have seemed to be bizarre as well as the situation of accessibility to medicines, vaccines and devices (p.848). McKee (2018) also underlined that a no-deal outcome would have immediately deprived the UK's medical sector of the EU's large-scale funding opportunities. This would furthermore have had a negative impact on the mobility and cooperation of high-skilled international academicians as well as students in this sector. The increase of national health care spending due to fall in tax revenues, had been likely to lead to restrictions in spending within other policy fields (Lea, 2018, p.4). Yet, the significance of supporting and strengthening the health sector and the right to health as a fundamental right have unfortunately been experienced quite severely during the Covid-19 pandemic throughout the whole World, but particularly in the UK.

A further negative impact was likely to be revealed in the agri-food sector. The hit in this sector was likely to lead to shortages of major food products and also higher prices for consumers. This would have been caused by the high customs tariffs to be imposed between the sides and their additional costs as well as the veterinary checks to be conducted at the border (Mc Kee, 2018).

Last but not the least, the situation of the citizens of both parties was another significant topic to be dealt with. British citizens in case of a no-deal withdrawal immediately would have been counted as third country citizens to whom Council Regulation (EU) 2018/1806 ${ }^{4}$ had been needed to be applied. For the sake of preserving the acquired rights of both British citizens living and working in EU Member States as well as European citizens living and working in the UK, the parties should have tried to seek ways for reaching a compromise for the most effective solution particularly in the fields related to social security and pension transferability (Wolff, 2019, pp.6-7).

${ }^{4}$ Regulation (EU) 2018/1806 of the European Parliament and of the Council of 14 November 2018 listing the third countries whose nationals must be in possession of visas when crossing the external borders and those whose nationals are exempt from that requirement, PE/50/2018/REV/1, OJ L 303, 28.11.2018, p. 39-58. 
One has to note that the immediately affected sectors in case of a withdrawal without a deal should not have been the ones limited to those mentioned above. However, also it has to be underlined that the European Commission tried to make all the necessary rapid preparations and submit emergency drafts with regard to several sectors in order to avoid troublesome outcomes (Wolff, 2019, p.7).

As said earlier, a no-deal scenario after so long-lasting efforts and negotiation processes conducted between the UK and the EU for the last three and a half years till January 2020, would have seemed to put everything in vain. McKee (2018) pointed out to a report that had been prepared by the House of Lords which could be summarized shortly in one sentence. According to that, "a no-deal consequence was most probably the worst of all other scenarios for the UK". Therefore, the terms and conditions of the Withdrawal Agreement shall better be read and evaluated only after elaborating on the possible negative effects of a past no-deal situation in order to achieve a more efficient and effective understanding.

\section{A Brief Overview of the Negotiations during the Covid-19 Pandemic}

On the other side one shall still keep in mind that the fact that a nodeal scenario did not come true for the first level of the game does not mean that there exists no such further possibility within the second level of the same game. The negotiations conducted between the UK and the EU still heavily carry the risk of being concluded without any trade deal at the end of the transition period. As mentioned earlier, this shall mean that the UK might start to trade with the EU on WTO terms by the start of 2021 unless a further extension is not demanded or provided (Landler \& Castle, 2020).

Currently both the UK and the EU side have been negotiating through video conference calls in terms of setting up a new trade deal as well as determining on the conditions and terms of their future relationship. The sides' relationship has already been deteriorated by the impacts of Covid-19 pandemic which has emerged as a disastrous nightmare still affecting the whole World countries. It's undeniable that the Brexit negotiations between the sides have lost their priorities when the new agenda was replaced by the Coronavirus pandemic and the ways to struggle with it (Landler \& Castle, 2020).

The on-going negotiations yet provide little evidence on whether or not the sides will be able to conclude a deal before December 31, 2020. The British government seems to avoid asking for any extension of the transition period. As rightfully put forward by Conley (2020) the Withdrawal Agreement does not provide itself the opportunity to ask for a further extension of the transition period unless it is changed. The EU officials state that the sides were 
unsuccessful in making any significant progress so far. Johnson's government seeks to catch up a more distant and independent relationship with the EU. This largely seems to contradict with the EU's approach which seeks to guarantee a level playing field particularly through providing that the UK will still remain to be bound with EU state aid rules (Sandford, 2020; Boffey, 2020).

There are still several other topics which are hotly debated between the two parties. According to the EU side, the British side has been moving too slow in guaranteeing minimum levels of standards with regard to areas such as environment, workers' rights as well as the protection of personal data. Moreover, the EU keeps insisting on that the UK should continue implementing the European Convention on Human Rights through incorporating it into its national legal system and the disputes should be resolved by the European Court of Justice. This is not accepted by the British side since it is not willing to be bound by a foreign court's decisions. The UK also considers that the EU has been treating third countries such as Canada more favorably in comparison to what it has been offered as an ex-member in terms of a trade deal. The UK also is unlikely to allow the EU Member States to have access to its fishing stocks which is another unresolved issue between the parties (Conley, 2020).

According to some commentators, the Covid-19 pandemic and its expected catastrophic effects on economies, might even lead the British government to seek for a far more independent relationship with the EU for reshaping its economy and coping against the global recession. This might eventually increase the possibility for the UK and the EU trade talks to be concluded without any trade deal (Landler \& Castle, 2020). Considering that the Conservatives and particularly Johnson has come out of the December 2019 elections with holding such a large majority in the new British Parliament ever since Margaret Thatcher's election, there no longer seems any need to arrive at a compromise with the EU for guaranteeing the British Parliament's support (Conley, 2020) which is likely to put the situation into more difficulty. Some commentators even suggest that the likely negative outcomes of Brexit will be overshadowed by the larger negative impacts of the coronavirus on economies notably British economy, so that it would almost become impossible to recognize any difference (Landler \& Castle, 2020). British citizens would be unlikely to make a division between the disastrous economic ramifications of Covid-19 and the economic hardship caused by being subject to WTO tariff schedules under a likely no-deal or a minimum deal scenario which accounts for an almost no-deal (Conley, 2020). Therefore, all what have been mentioned above, accompanied by the red lines of both sides have unfortunately raised serious concerns in terms of a no-deal scenario at the end of 2020 (Sandford, 2020; Boffey, 2020). 


\section{Concluding Remarks}

It is undoubted that the year 2020 shall be reminded as a year full of remarkable events even when the first half is considered. Early this year, one of the strongest Member States of the EU officially became an ex-member which happened for the first time in the EU integration history. This was significant in terms of being the first case of withdrawal, however it was more striking that the country closing the door behind was also one of the wealthiest and powerful members of the EU which at the end of the day would mean a lot for the whole European integration project.

This study sought to briefly analyse the legal, political as well as economic consequences of this divorce process from a general view by particularly trying to focus on the details of the most controversial aspects of what had been negotiated between the sides on the table. Moreover, a comprehensive comparison has been drawn between the outcomes of exiting from the EU with a withdrawal agreement and without any deal. The outcomes reveal that the Brexit process which has started four years ago shall not be as easy -for particularly the UK part- as it was envisaged to be. The whole process already seems to be sufficiently rocky ranging from the legal outcomes to the economic ones which under each scenario are likely to encounter serious negative impacts in comparison to preserving the full membership. Yet, the sides are divorced and the clock has this time been ticking for setting up a new trade relationship until the end of this year which shall most probably be no easier than the first round of negotiations.

However, this historic experience has shown certain lessons to be drawn for other Member States of the EU. Though, there is still little evidence suggesting what price is to be paid in terms of Brexit both by the UK and the EU side, at least, what is clear is that the UK within this process unfortunately understood that it could not still have its cake and eat it as it was used to during the last 47 years of this marriage.

\section{References:}

1. Apolte, T. (1997). Secession Clauses: A tool for the Taming of an Arising Leviathan in Brussels. Constitutional Political Economy. 8(1), 57-70.

2. Berglund, S. (2006). Prison or Voluntary Cooperation? The Possibility of Withdrawal from the European Union. Scandinavian Political Studies. 29(2), 147-167.

3. Bicer, A. (2019, November 13). In Era of Change, Frankfurt Poised to Claim Global Finance Crown. Anadolu Agency. https://www.aa.com.tr/en/economy/in-era-of-change-frankfurtpoised-to-claim-global-finance-crown/1643504. 
4. Boffey, D. (2020, May 19). Brexit talks: Britain accuses EU of threating UK as 'unworthy' partner. The Guardian. https://www.theguardian.com/politics/2020/may/19/brexit-talks-euwants-us-to-obey-the-rules-of-their-club-says-gove.

5. Brexit: MPs reject May's EU withdrawal agreement. (2019, March 30). BBC News. Retrieved January 12, 2020 from https://www.bbc.com/news/uk-politics-47752017.

6. Carmona, J., C.-C. Cîrlig and G. Sgueo. (2017). UK Withdrawal from the European Union, Legal and Procedural Issues. European Parliamentary Research Service. http://www.europarl.europa.eu/RegData/etudes/IDAN/2017/599352/ EPRS_IDA(2017)599352_EN.pdf

7. Cini M. and A. Verdun. (2018). The Implications of Brexit for the Future of Europe. In Martill B. and U. Staiger, (eds.) Brexit and Beyond, Rethinking the Futures of Europe. UCL Press. London. 6371.

8. Cliffe, J. (2020). The End of the Affair. New Statesman. 149 (5505), $22-25$.

9. Coe, J. (2019). How Brexit Broke Britain, Time International (Asia edition) 193(23), 32-35.

10. Conley, H.A. (2020, May 7). Covid-19 May Encourage a No-deal Brexit. Center for Strategic and International Studies. https://www.csis.org/analysis/covid-19-may-encourage-no-dealbrexit.

11. Darvas, Z. (2019, January 14). EU Budget Implications of a No-deal Brexit. https://bruegel.org/2019/01/eu-budget-implications-of-a-nodeal-brexit.

12. Dominiczak, P. (2017, January 1). Brexit: Theresa May tells EU that 'no-deal is better than a bad deal for Britain'. The Telegraph. https://www.telegraph.co.uk/news/2017/01/17/brexit-theresa-maytells-eu-no-deal-better-bad-deal-britain/.

13. Emerson, M. (2016). The Final Brexit Question, The Known Plan A to remain or the unknown Plan B to leave. CEPS Working Document. No.418.

14. Elliot, L. (2019, July 18). No-deal Brexit would plunge Britain into a recession, says OBR. The Guardian. http://www.theguardian.com.

15. European Commission Fact Sheet, Protocol on Ireland and Northern Ireland, Questions \& Answers. (2018, November 14). Brussels. europa.eu/rapid/press-release_MEMO-18-6423_en.pdf.

16. EU Reform Deal: What Cameron Wanted and What He Got. (2016, February 20). BBC News. Retrieved January 20, 2020 from https://www.bbc.com/news/uk-politics-eu-referendum-35622105. 
17. EU Referendum Results, UK Votes to Leave the EU. BBC News. $\begin{array}{llll}\text { Retrieved January } 25, & 2020 & \text { from }\end{array}$ https://www.bbc.com/news/politics/eu_referendum/results.

18. Explainer for the Political Declaration setting out the framework for the future relationship between the United Kingdom and the European Union. (2018, November https://www.gov.uk/government/publications/withdrawal-agreementand-political-declaration

19. Explainer for the agreement on the withdrawal of the United Kingdom of Great Britain and Northern Ireland from the European Union. (2018, November

https://www.gov.uk/government/publications/withdrawal-agreementand-political-declaration.

20. Flavier H. and Sébastien P. (2016, August 30). Brexit: A Tale of Two Agreements? Luropean Baw Blog. https://europeanlawblog.eu/2016/08/30/brexit-a-tale-of-twoagreements/.

21. Gamble, A. (2012). Better Off Out? Britain and Europe. The Political Quarterly. 83(3), 468-477. https://doi.org/10.1111/j.1467923X.2012.02346.X.

22. Hantzsche, A., A. Kara and G. Young. (2019). The economic effects of the UK government's proposed Brexit deal. The World Economy. 42(1), 5-20.

23. Henley, J. (2019, June 11). Brexit: EU will not reopen withdrawal agreement, insists French Minister. The Guardian,

24. https://www.theguardian.com/politics/2019/jun/11/no-renegotiationwithdrawal-agreement-french-minister.

25. House of Commons vote on no-deal Brexit. (2019, March 13). Retrieved February $\quad 8, \quad 2020$ from https://www.parliament.uk/business/news/2019/march/house-ofcommons-to-vote-on-no-deal-brexit/.

26. Isaby, J. (2019, May 2). Theresa May suggests her 'no-deal is better than a bad deal' mantra only applied 'in the abstract'. Brexit Central. https://brexitcentral.com/theresa-may-suggests-her-no-deal-is-betterthan-a-bad-deal-mantra-only-applied-in-the-abstract/.

27. Kentish, B. (2019, March 12). Brexit Backstop: What is the Irish border plan and why is it so controversial? The Independent. https://www.independent.co.uk/news/uk/politics/brexit-what-isbackstop-northern-ireland-irish-border-guarantee-may-deala8678306.html

28. Landler M. and S. Castle (2020, June 5). How the Coronavirus Makes a No-deal Brexit More Likely. The New York Times. 
https://www.nytimes.com/2020/06/05/world/europe/brexitcoronavirus-uk.html.

29. Lea, R. (2018, September 3). The pace of UK-EU Brexit negotiations is picking up, and the UK prepares for 'no-deal'. Perspectives. Arbuthnot Banking Group PLC, https://www.arbuthnotlatham.co.uk/wp-content/uploads/2018/09/3rdSeptember-2018.pdf

30. Mackrell, D. (2019, June 6). When does Theresa May resign and leave her position as Prime Minister. Metro News. https://metro.co.uk/2019/06/06/theresa-may-resign-leave-positionprime-minister-9839912.

31. Martill, B. and U. Staiger (2018). Introduction Brexit and beyond. In Martill B. and U. Staiger, (eds.) Brexit and Beyond, Rethinking the Futures of Europe. UCL Press. London. 1-21.

32. Mc Grath, C. (2018, October 20). Brexit Power Grab: 'Unrealistic' Frankfurt aims to replace London as EU financial capital. Express. https://www.express.co.uk/news/politics/1033983/brexit-newslondon-financial-centre-frankfurt-germany-greg-hands.

33. Mc Kee, M. (2018, January 1). What would a 'no-deal' Brexit meanand what does it tell us about those who want it? The BMJ, Observations.

34. https://www.bmj.com/content/360/bmj.k189.

35. https://doi.org/10.1136/bmj.k189.

36. Nugent, N. (2018). Brexit, Yet another crisis for the EU. In Martill B. and U. Staiger, (eds.) Brexit and Beyond, Rethinking the Futures of Europe. UCL Press. London. 54-62.

37. Nicolaides, P. (2013). Withdrawal from the European Union: A Typology of Effects. Maastricht Journal of European and Comparative Law. 20(2), 209-219.

38. O’Carroll, L. (2019, October 17). How is Boris Johnson's Brexit Deal Different from Theresa May's? The Guardian. https://www.theguardian.com/politics/2019/oct/17/how-is-borisjohnson-brexit-deal-different-from-theresa-may.

39. Patel, K.K. (2018). Something New under the Sun? The Lessons of Algeria and Greenland. In Martill B. and U. Staiger, (eds.) Brexit and Beyond, Rethinking the Futures of Europe. UCL Press. London. 114123.

40. Paterson, W.E. (2018). Britain's Singular Other-Germany and the Brexit Crisis. In Martill B. and U. Staiger, (eds.) Brexit and Beyond, Rethinking the Futures of Europe. UCL Press. London. 88-96.

41. Piris, J-C. (2016). If the UK votes to leave, The Seven Alternatives to EU Membership. Centre for European Reform. 
https://www.cer.org.uk/sites/default/files/pb_piris_brexit_12jan16.pd $\mathrm{f}$

42. Rankin, J. (2016, February, 19). David Cameron's EU Deal: What He Wanted and What He Got. The Guardian. https://www.theguardian.com/world/2016/feb/19/camerons-eu-dealwhat-he-wanted-and-what-he-got.

43. Rankin, J. (2019, July 29). Complete Breakdown': EU rejects Dominic Raab's 'easier' no-deal Brexit claim. The Guardian. https://www.theguardian.com/politics/2019/jul/29/eu-officials-rejectdominic-raabs-easier-no-deal-brexit-claim.

44. Revised Protocol on Ireland and Northern Ireland included in the Withdrawal Agreement. (2019, October 17). TF50(2019) 64Commission to EU 27, https://ec.europa.eu/commission/sites/betapolitical/files/revised_withdrawal_agreement_including_protocol_on _ireland_and_northern_ireland.pdf.

45. Statistics on UK-EU Trade (2019, July 24). House of Commons Library, Retrieved September 1, 2019 from https://researchbriefings.parliament.uk/ResearchBriefing/Summary/C BP-7851

46. Sandford, A. (2020, June 5). Post-Brexit Guide: Where are we nowand how did we get here? Euronews. https://www.euronews.com/2020/02/11/brexit-draft-deal-first-ofmany-hurdles-to-a-smooth-exit.

47. Spencer, S. (2019, March 2). Brexit: Deal or No-deal? The Lancet. 393(10174):848. doi: 10.1016/S0140-6736(19)30443-X.

48. Taylor, C. (2018, October 22). Brexit Explained: What is the Transition Period and Why is it so Important? Irish Times.

49. https://www.irishtimes.com/news/world/europe/brexit-explainedwhat-is-the-transition-period-and-why-is-it-so-important-1.3671622.

50. The Real Danger of Brexit. (2016, February 27-March 4). The Economist. https://www.economist.com/leaders/2016/02/27/the-realdanger-of-brexit.

51. Walker, P. (2019, October 21). What does Boris Johnson's Withdrawal Bill Actually Say? The Guardian. https://www.theguardian.com/politics/2019/oct/21/what-does-borisjohnsons-withdrawal-bill-actually-say.

52. Walker, P. (2019, July 31). Dominic Raab to urge firms to focus more on exporting outside EU. The Guardian. http://www.theguardian.com/politics/2019/jul/31/dominic-raab-tourge-firms-to-focus-more-on-exporting-outside-eu-business-trade.

53. Wolff, G. B. (January 2019). The implications of a no-deal Brexit: is the European Union prepared? Policy Contribution. Issue 2. 
http://bruegel.org/wp-content/uploads/2019/01/PC-2019-02140119.pdf.

54. Wright G. and J. Naselli. (2018, November 16). In Brexit Negotiations, Both Sides Have Now Compromised. www.chathamhouse.org/Brexit/Backstop.

55. 1975:UK Embraces Europe in Referendum, On This Day 1950-2005. BBC News Home. Retrieved December 10, 2019 from http://news.bbc.co.uk/onthisday/hi/dates/stories/june/6/newsid_24990 00/2499297.stm 